\title{
Instructive Indicators of Sustainable Livelihood in Poverty Moderation: A Case Study
}

\author{
${\text { Chhaya } \text { Yadav }^{1} \text {, S.P.Lal }}^{2}$, K.Lal $^{3}$ \\ ${ }^{1}$ (Central Library, B.I.T Mesra Patna Campus, India) \\ ${ }_{2}^{2}$ Department of Production Engineering, B.I.T Mesra Patna Campus, India) \\ ${ }_{3}^{3}$ (Department of Computer Science \& Engineering, B.I.T Mesra Patna Campus, India)
}

\begin{abstract}
A livelihood is sustainable when it can cope with and recover from stresses and shocks and maintain or enhance its capabilities and assets both now and in the future, while not undermining the natural resource base. The unique livelihood strategy makes rural people exclusive from other parts of any country. Uprising problem is common in similar regions, which need to be sorted out with a detailed perspective on people and their living condition. Finding indicators is a way to improve understanding of the livelihoods of poor people. It draws on the main factors that affect poor people's livelihoods and the typical relationships between these factors. It can be used in planning new development activities and in assessing the contribution that existing activities have made to sustaining livelihoods.
\end{abstract}

Keywords: Sustainability, Indicators, ICT, SLD, SLA, Primary data

\section{INTRODUCTION}

Poverty has most commonly been assessed against income or consumption criteria. In this interpretation, a person is poor only if his/her income level is below the defined poverty line, or if consumption falls below a stipulated minimum. However, when the poor themselves are asked what poverty means to them, income is only one of a range of aspects which they highlight. Others include: a sense of insecurity or vulnerability; lack of a sense of voice vis-à-vis other members of their household, community or government; and levels of health, literacy, education, and access to assets, many of which are influenced by the scope and quality of service delivery.

Dissatisfaction with the income/consumption model gave rise to basic needs perspectives which go far beyond income, and include the need for basic health and education, clean water and other services which are required to prevent people from falling into poverty. More recently, poverty has been defined in terms of the absence of basic capabilities to meet these physical needs, but also to achieve goals of participating in the life of the community and influencing decision-taking. According to Robert Chambers and Gordon Conway, "A livelihood is sustainable when it can cope with and recover from stresses and shocks, maintain and enhance its capabilities and assets, and provide sustainable livelihood opportunities for the next generation; and which contribute net benefits to other livelihoods at the local and global levels and in the short and long term" (Chambers and Conway 1992).[1]

SLA is an example of the "multiple capital" approach where sustainability is considered in terms of available capital (natural, human, social, physical and financial) and an examination of the vulnerability context (trends, shocks and stresses) in which these assets exist. An outline of SLA and suggestions for putting it into practice can be found in "guidance notes" produced by DFID (available at www.nssd.net/references/SustLiveli/). Five principal assets (or capitals) are suggested as important to livelihood and they are presented as a pentagon in Figure 1

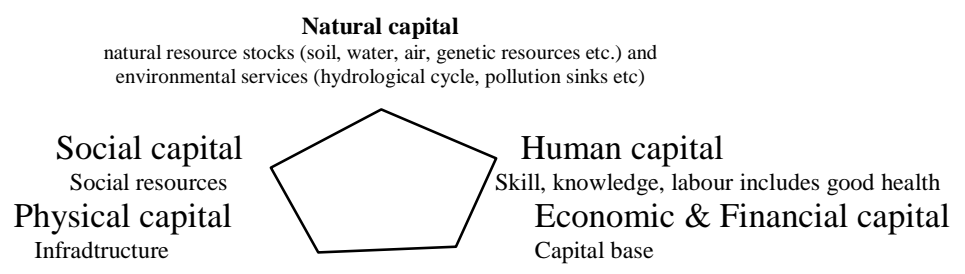

Fig 1. The five capitals of sustainable livelihood (after Scoones 1998)[2]

Indicators can provide crucial guidance for decision-making in an organization in variety of ways. They can translate physical and social science knowledge into manageable units of information that can facilitate the 
decision-making process. They can help to measure and calibrate progress towards sustainable development goals. They can provide an early warning, sounding the alarm in time to prevent economic, social and environmental damage. They are also important tools to communicate ideas, thoughts and values.

They are like early warning systems, which, when carefully designed, closely watched, and wisely interpreted, can not only show the critical aspect of the socio-economic-environmental status of the community but also influence the policy decisions, monitor their effectiveness and facilitate community action (DEAT,2001).

\section{PROBLEM DEFINITIONS}

Applying effort in unguided direction is simply wastage of energy, strategy, economy and moreover time. The same logic applied here in sustainable livelihood i.e applying efforts in all the areas without knowing proper direction. If we could know the actual factor affecting the sustainable livelihood, poverty can be alleviated. The indicators are playing vital role in this direction. The main problem is, researchers are not finding the root cause of the problem. Here finding indicators are most important work for sustainable livelihood. If we could identify it then $80 \%$ work is being completed.

To achieve sustainable livelihood by poverty moderation and identification of the cause of poverty can be identified by the help of suitable indicator. We can achieve sustainable livelihood through identification of the indicators among SLD, which is important in poverty alleviation.

\section{PREVIOUS WORK}

UNDP adopts Employment and Sustainable Livelihoods as one of five priorities in its overall human development mandate, to serve as both a conceptual and programming framework for poverty reduction. IISD publishes Adaptive Strategies and Sustainable Livelihoods (Singh and Kalala, 1995), the report of a UNDPfunded programme .SID launches project on Sustainable Livelihoods and People's Everyday Economics. In 1996, Adaptable Livelihoods: coping with food insecurity in the Malian Sahel(Davies, 1996) is published by Macmillan. DFID invites proposals for major ESCOR research programme on Sustainable Livelihoods..In 1998, DFID's Natural Resources Department opens a consultation on sustainable livelihoods and establishes a Rural Livelihoods Advisory Group.UNDP publishes Policy Analysis and Formulation for Sustainable Livelihoods (Roe, 1998).DFID establishes the SL Virtual Resource Centre and the SL Theme Group.IDS publishes "Sustainable rural livelihoods: a framework for analysis" (Scoones, 1998).The FAO/UNDP Informal Working Group on Participatory Approaches and Methods to Support Sustainable Livelihoods and Food Security meets for the first time. In 1999 DFID creates the Sustainable Livelihoods Support Office and appoints Jane Clark as its Head. DFID publishes the first Sustainable Livelihoods Guidance Sheets. DFID also publishes Sustainable Livelihoods and Poverty Elimination (DFID, 1999) and Livelihoods Approaches Compared (Carney et al., 1999). ODI publishes "Sustainable Livelihoods in Practice: early application of concepts in rural areas" (Farrington et al., 1999). In 2000 DFID commissions and funds Livelihoods Connect, a website serving as a learning platform for SLA.

IDS publishes Analyzing Policy for Sustainable Livelihoods (Shankland, 2000), the final report from its ESCOR programme. In 2001, Millennium Development Goals established. DFID commissions research on further development of the SLA framework; practical policy options to support sustainable livelihoods. DFID organizes SLA review meeting of officials, researchers and practitioners.

In 2002: World Summit on Sustainable Development (Earth Summit 2002) takes place in Johannesburg, South Africa.[3]

\section{Comparing Three Distinct Areas Of India}

(RANCHI, GHAZIPUR AND KORBA)

In this study we have decided to take up three case studies in three States: Jharkhand (Ranchi district), Utter Pradesh (Ghazipur district) and Chhattisgarh (Korba district) different regions of India.

Table 1: District Profile (Sources: http://www.census2011.co.in )

\begin{tabular}{|l|c|c|c|}
\hline ITEM & RANCHI & GHAZIPUR & \multicolumn{1}{l|}{ KORBA } \\
\hline Geographical Area & $5231 \mathrm{sq} \mathrm{Kms}$ & $3,384 \mathrm{Sq} . \mathrm{Km}$. & $7145.44 \mathrm{sq} \mathrm{Km}$. \\
\hline Population & 2914253 & $3,620,268$ & 1206640 \\
\hline \% of Scheduled Caste & 5 & 21.38 & 9.98 \\
\hline \% of Scheduled tribe & 41.81 & 0.01 & 41.49 \\
\hline Density of population in per sq. & 572 & 1072 & 183 \\
\hline
\end{tabular}


Instructive Indicators of Sustainable Livelihood in Poverty Moderation: A Case Study

\begin{tabular}{|l|c|c|c|}
\hline $\mathrm{km}$ & & & \\
\hline \% of Urban population & 43.14 & 7.58 & 36.99 \\
\hline \% of Rural population & 56.86 & 92.42 & 63.01 \\
\hline Sex Ratio & 949 & 952 & 969 \\
\hline \% of Literacy & 76.06 & 71.78 & 72.37 \\
\hline
\end{tabular}

JHARKHAND: Jharkhand is endowed with a wide variety of natural resources and is one of the most attractive destinations because of its natural wealth, coupled with its skilled and industrious people, low cost of living and great industrial climate. Since its creation, the state has set in place a range of enablers for investment. Today with its investment friendly climate and expertise in geology, mining and immense power potential, Jharkhand has the potential to become the most financially viable state in the country. At present major industrial centres in the state are Tatanagar, Bokaro steel city, Dhanbad, Ranchi, Deoghar and Hazaribagh.'

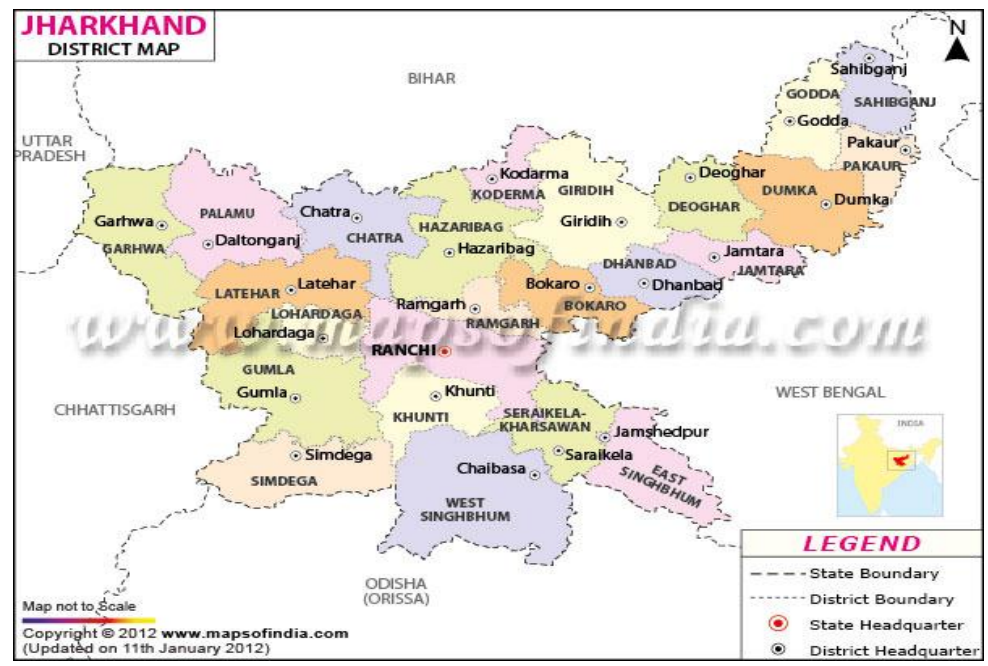

Fig 2: Map of Jharkhand

The vast potential that state posses is lying unexplored domestically and internationally, with miniscule export figures. Also, there are no reliable statistics available. According to the Export Potential Survey of Jharkhand conducted in year 2005-06, exports stood at $\$ 17$ million. There is much potential in exports of silk, handicrafts, automobile etc. Due to the lack of exports figures, we have to rely on the regional figures. Eastern region including Jharkhand contributes 10\% to India's exports. Keeping in view the immense and untapped potential of the eastern region, exports can be grown to $20 \%$ by the year 2020. [4]

UTTAR PRADESH: In Uttar Pradesh, Forests constitute about $12.8 \%$ of the total geographical area of the state. The Himalayan region and the terai and bhabhar area in the Gangetic plain have most of the forests. The Vindhyan forest consists mostly of scrub. The districts of Jaunpur, Ghazipur and Ballia have no forest land, while 31 other district have less forest area.

The minerals found in Uttar Pradesh include limestone which is found in Guruma-Kanach- Bapuhari in Mirzapur district and Kajrahat in Sonebhadra district; dolomite which is found in Mirzapur, Sonebhadra and Banda, glasssand found in Karchhana tehsil of Allahabad district, Karwi in Banda district and Mau district; marble found in Mirzapur and Sonebhadra; bauxite found in Rajhgewan in Banda district; non-plastic fireclay found in Bansi, Makri-Khoh area of Mirzapur district; and Uranium found in Lalitpur district. Besides, Barytes and Edalusite are found in the districts of Mirzapur and Sonebhadra. Sand-stone, pebbles, reh, salt punter, marang, sand and other minor minerals are also found in the State.

Rivers are Ganga, Yamuna, Gomti, Ramganga \& Ghaghara.[5]Poverty levels that are higher than the average for rural India[6] People belonging to socially excluded groups form a substantial proportion of the district's total population.[7] 


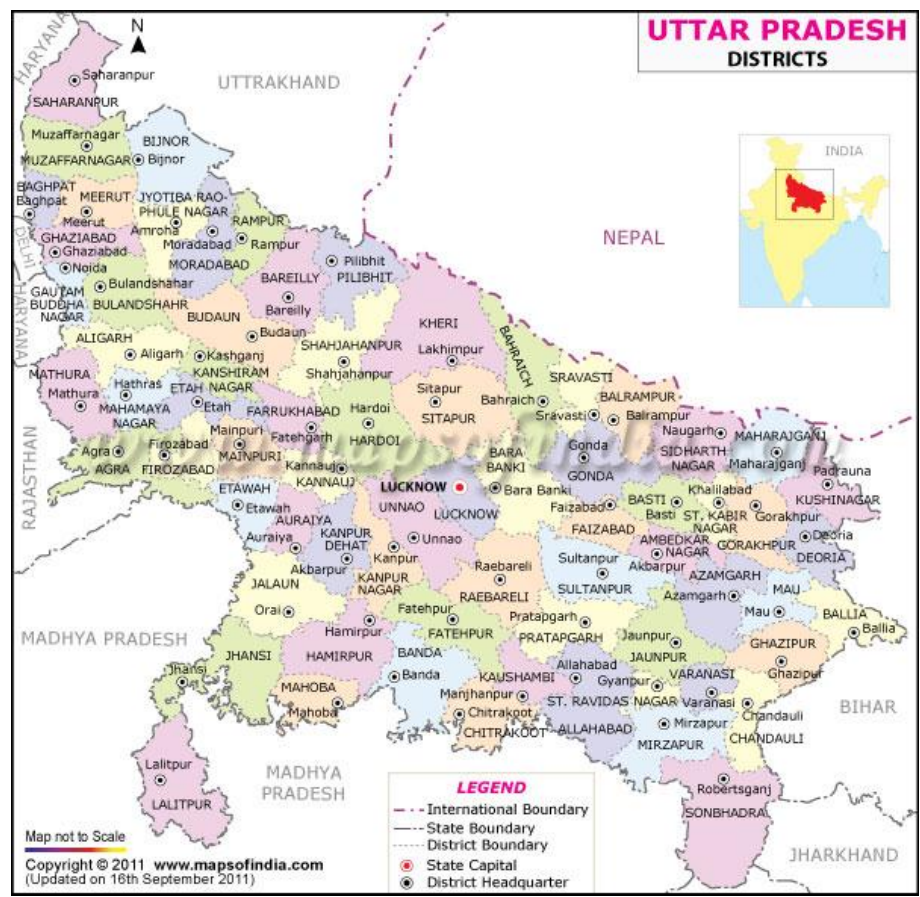

Fig 3: Map of Uttar Pradesh

CHHATTISGARH: Agriculture is the primary occupation of the people of Chhattisgarh. About $80 \%$ of the population depend on it for their livelihood. It is thus vital to the economy of the State, and any initiatives undertaken in this sector would have a lasting impact on the economy. Water being an important input for sustaining agricultural activities, its effective utilization becomes vital for economic development. Chhattisgarh has sufficient water resources, but this resource largely remains untapped. In terms of the irrigation potential, it is estimated that 43-lakh hectare area can be irrigated as against the existing irrigation potential of 1.34 lakh hectare.

Forestry has a significant role in the economic development of Chhattisgarh. $44 \%$ of the State is covered with forests, ranking it third in India in terms of forest cover. The State boasts of an abundance of minor forest produce like Tendu leaves, Sal seed, Myrobolan,Mahua seed, gum, etc., which have enormous economic potential.Chhattisgarh has not fully realized the potential of its abundant mineral wealth. The presence of vast reserves of coal, iron ore, limestone, diamond, etc. have positioned the State second in the country's list of mineral producing states. [ 8]

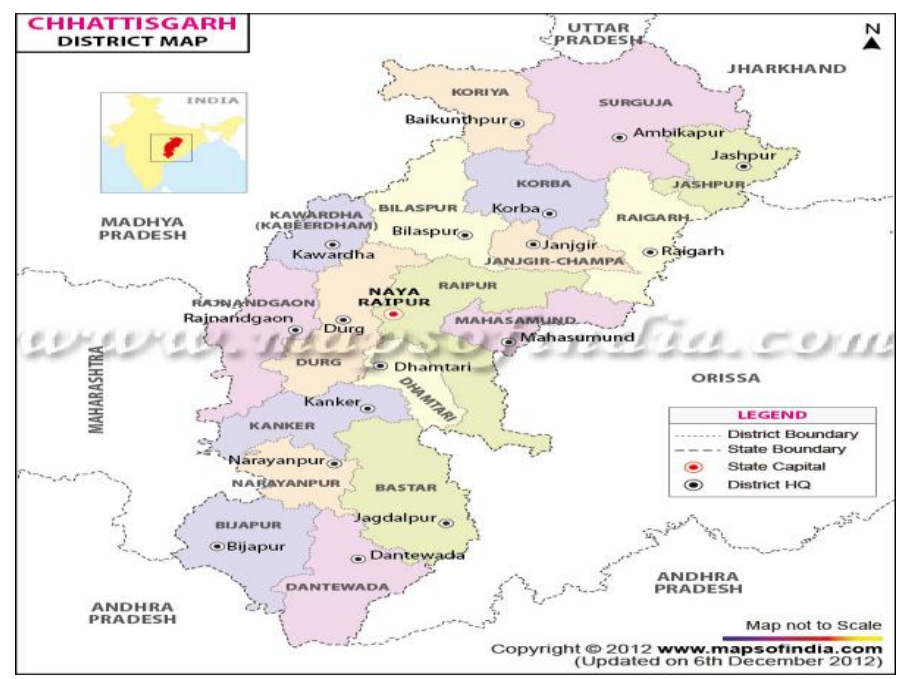

Fig 4: Map of Chhattisgarh

Above districts therefore present varied resource base, ecological setting, and physical constraints that have bearing on poverty. Understanding of poverty prevalence in such contrasting situations presents an interesting sample of comparative study of poverty. 
Table 2: Numbers of Households with landholding size in three different regions

\begin{tabular}{|c|c|c|c|}
\hline Land Holding Size & $\begin{array}{c}\text { (Nayatoli)Ran } \\
\text { chi }\end{array}$ & $\begin{array}{c}\text { (Gopalpur)Gha } \\
\text { zipur }\end{array}$ & ( Jhabar)Korba \\
\hline Landless & 13 & 10 & 31 \\
\hline < acres & 58 & 87 & 11 \\
\hline $\mathbf{2 - 5}$ acres & 26 & 03 & 57 \\
\hline $\mathbf{5 - 1 0}$ acres & 3 & 00 & 1 \\
\hline$>\mathbf{1 0}$ acres & 00 & 00 & 0 \\
\hline Total & 100 & & 100 \\
\hline
\end{tabular}

Source: Primary data collected from household survey.

Table 3 : Education in three different villages.

\begin{tabular}{|l|c|c|c|}
\hline Education & $\begin{array}{l}\text { (Nayatoli)Ranc } \\
\text { hi }\end{array}$ & $\begin{array}{l}\text { (Gopalpur)Ghazip } \\
\text { ur }\end{array}$ & (Jhabar)Korba \\
\hline Primary school pass & 133 & 392 & 112 \\
\hline Middle school pass & 102 & 77 & 52 \\
\hline $\mathbf{1 0}^{\text {th }}$ Pass & 157 & 46 & 164 \\
\hline $\mathbf{1 2}^{\text {th }}$ Pass & 120 & 18 & 32 \\
\hline Graduate & 60 & 4 & 64 \\
\hline Professionals & 25 & & 20 \\
\hline
\end{tabular}

Table 4: Income of People in three different regions.

\begin{tabular}{|c|c|c|c|}
\hline $\begin{array}{c}\text { Income Per month(in } \\
\text { Rs) }\end{array}$ & $\begin{array}{c}\text { (Nayatoli) } \\
\text { Ranchi }\end{array}$ & $\begin{array}{c}\text { (Gopalpur)Ghazip } \\
\text { ur }\end{array}$ & $\begin{array}{c}\text { (Jhabar)Kor } \\
\text { ba }\end{array}$ \\
\hline $0-5000$ & 5 & 27 & 44 \\
\hline $5000-10000$ & 50 & 55 & 28 \\
\hline $10000-15000$ & 17 & 4 & 0 \\
\hline $15000-20000$ & 19 & 7 & 12 \\
\hline Above 20000 & 9 & 7 & 16 \\
\hline
\end{tabular}

Table5: Expenditure in three different regions.

\begin{tabular}{|c|c|c|c|}
\hline $\begin{array}{c}\text { Expenditure Per week(in } \\
\text { Rs) }\end{array}$ & $\begin{array}{c}\text { (Nayatoli) } \\
\text { Ranchi }\end{array}$ & $\begin{array}{c}\text { (Gopalpur) } \\
\text { Ghazipur }\end{array}$ & $\begin{array}{c}\text { (Jhabar) } \\
\text { Korba }\end{array}$ \\
\hline $0-1000$ & 50 & 94 & 53 \\
\hline $1000-2000$ & 47 & 6 & 44 \\
\hline $2000-5000$ & 3 & 0 & 3 \\
\hline $5000-10000$ & 0 & 0 & 0 \\
\hline
\end{tabular}

Table 6: Type of House in three different regions.

\begin{tabular}{|l|c|l|l|}
\hline House Type & $\begin{array}{c}\text { (Nayatoli) } \\
\text { Ranchi }\end{array}$ & (Gopalpur)Ghazipur & $\begin{array}{l}\text { (Jhabar)Korb } \\
\mathrm{a}\end{array}$ \\
\hline Kutcha House & 74 & 11 & 16 \\
\hline Pucca House & 26 & 89 & 84 \\
\hline
\end{tabular}


Table 7: Sanitation in three different regions

\begin{tabular}{|l|l|l|l|}
\hline Toilet & \multicolumn{1}{|c|}{$\begin{array}{c}\text { (Nayatoli) } \\
\text { Ranchi }\end{array}$} & (Gopalpur)Ghazipur & (Jhabar)Korba \\
\hline Yes & 22 & 17 & 44 \\
\hline No & 78 & 83 & 56 \\
\hline
\end{tabular}

Table8 : Agricultural methods used in houses.

\begin{tabular}{|l|c|c|c|}
\hline Village/methods & $\begin{array}{l}\text { (Nayatoli) } \\
\text { Ranchi }\end{array}$ & $\begin{array}{l}\text { (Gopalpur) } \\
\text { Ghazipur }\end{array}$ & $\begin{array}{l}\text { (Jhabar) } \\
\text { Korba }\end{array}$ \\
\hline Old or manual methods of farming & 61 & 69 & 59 \\
\hline fertilizers & 14 & 21 & 11 \\
\hline Fertilizers with treated seeds & 16 & 4 & 5 \\
\hline $\begin{array}{l}\text { treated seeds with green manures and } \\
\text { vermi-compost, Inter cropping methods }\end{array}$ & 7 & 5 & 2 \\
\hline $\begin{array}{l}\text { Fertilizers, treated seeds,new irrigation } \\
\text { methods }\end{array}$ & 2 & 3 & 0 \\
\hline $\begin{array}{l}\text { Fertilizers, imported seeds, } \\
\text { New irrigations methods, new equipments } \\
\text { and training. }\end{array}$ & 0 & 0 & \\
\hline
\end{tabular}

Table9: ICT used in different villages.

\begin{tabular}{|l|c|c|c|}
\hline ICT instruments \& facility/Village & $\begin{array}{c}\text { (Nayatoli) } \\
\text { Ranchi }\end{array}$ & $\begin{array}{c}\text { (Gopalpur) } \\
\text { Ghazipur } \\
\text { Korba }\end{array}$ & 47 \\
\hline Nil & 36 & 46 & 51 \\
\hline Mobile & 52 & 5 & 4 \\
\hline Radio, TV, mobile, & 8 & 1 & 0 \\
\hline Radio, TV, mobile, LL, & 2 & 1 & 1 \\
\hline Computers & 1 & 0 & 0 \\
\hline Internet, s/w, ATM, e-learning & 1 & & \\
\hline
\end{tabular}

Table10: Drinking water

\begin{tabular}{|c|c|c|c|}
\hline Sources/Villages & $\begin{array}{c}\text { (Nayatoli) } \\
\text { Ranchi }\end{array}$ & $\begin{array}{c}\text { (Gopalpur) } \\
\text { Ghazipur }\end{array}$ & $\begin{array}{c}\text { (Jhabar) } \\
\text { Korba }\end{array}$ \\
\hline Tap Water & 0 & 91 & 26 \\
\hline Well & 70 & 00 & 66 \\
\hline Boring & 5 & 02 & 06 \\
\hline Hand Pump & 25 & 7 & 02 \\
\hline
\end{tabular}

Table11: Cooking fuel

\begin{tabular}{|c|c|c|c|}
\hline Sources/Villages & $\begin{array}{c}\text { (Nayatoli) } \\
\text { Ranchi }\end{array}$ & $\begin{array}{c}\text { (Gopalpur) } \\
\text { Ghazipur }\end{array}$ & $\begin{array}{c}\text { (Jhabar) } \\
\text { Korba }\end{array}$ \\
\hline Leaf/wood/cow dung/ & 67 & 74 & 55 \\
\hline Kerosene oil & 02 & 03 & 01 \\
\hline LPG gas & 31 & 23 & 44 \\
\hline
\end{tabular}

Traditional biomass fuels (wood, charcoal, coal, twigs, agricultural wastes and animal dung) are the major source of energy in above villages. Three billion people globally use biomass fuels as their main source of domestic energy. It is estimated that about $30 \%$ of urban households and $90 \%$ of rural households in developing countries rely on traditional biomass fuels as the major, or only, source of domestic energy.

Biomass fuel use is the major cause of Indoor Air Pollution (IAP) in developing countries. Since biomass fuels are the dirtiest fuels, their combustion which mainly takes place in poorly ventilated areas and use inefficient indoor stoves leads to high levels of a number of health damaging pollutants such as particulate matter; carbon monoxide; nitrogen oxides; formaldehyde; benzene; 1,3 butadiene; polycyclic aromatic hydrocarbons and many 
other toxic compounds. Exposure to these pollutants in developing countries is reported to be higher in women and children. Exposure to pollution from biomass fuel combustion has been identified as an important health risk threat in developing countries. Cooking with biomass fuels and coal is estimated to cause $3 \%$ of all diseases worldwide. It has been shown that exposure to biomass fuel smoke is responsible for a number of respiratory diseases such as Acute Respiratory Infections (ARI), Chronic Obstructive Pulmonary Disease (COPD), Tuberculosis and Asthma; Low Birth Weight; Cataract and Blindness. [9]

\section{METHODOLOGY}

Algorithm / pseudo code is as follows:

Step I: Select SLD.

Step II: Assign weight factor $W_{f}$ to each SLD.

Step III: Set scheme to award value to each SLD.

Step IV: calculate weight of the indicator $W_{i}$ by finding $W_{s} \longleftarrow N_{h} * P_{t}$

Step V: Find Sum by caclulating sum $\leftarrow \sum_{i=1}^{n} W i$

Step VI: Find $S L D_{v}$ by multiplying $\sum W_{i} * W_{f}$

Step VII: Go to step I for each village.

Step VIII: Find three optimal SLD ${ }_{v}$ for each village using concept

a. find the $k$ 'th element in A using 'selection algorithm', let it be ' $z$ '

b. $\quad$ initialize an empty list ' $L$ '

c. $\quad$ initialize counter $<-0$

d. for each element in A:

e. $1 . \quad$ if element $<z$ :

e. 1.1. $\quad$ counter $<$-counter $+1 ;$ L.add(element)

f. for each element in A:

g.1. if element $==z$ AND count $<k$ :

g.1.1. counter<-counter $+1 ;$ L.add(element)

h. return $L$.

\section{A) Selection of Dimensions (SLD)/Indicators(SLI) for Rural sustainable livelihoods:}

i) Land: Natural capital includes all natural resource stocks such as land, ora and fauna, water, air and environmental services from which livelihoods are derived. In rural agrarian societies, the access to farm land and its ownership is crucial for sustaining livelihoods. These resources are also the economic capital because the access to land provides employment and income to farmers (De Janvry, 1981;Findley, 1987). In addition, the ownership of land is an important criterion in defining one's position in the socioepolitico-economic class hierarchy (De Janvry, 1981; Findley, 1987; Blaikie et al., 2002; Sudgen, 2009). The ownership of this most vital resource increases control over other resources such as income earned from land, political power, and access to other institutions, for example, banks. Nepal, the access to and ownership of land, in general, is associated with caste hierarchy with high caste farmers being the ones with most access to and ownership of land (Sudgen, 2009). Evidence suggests that an increase in the access to operational land educes the tendency to close down farms (Glauben et al., 2006; Goetz and Debertin, 2001; Kimhi and Bollman, 1999; Pietola et al., 2002). Large farms provide higher incomes to farmers and there-fore, increase farm survival (Kimhi and Bollman, 1999). Similarly,

Goetz and Debertin (2001) and Kimhi and Bollman (1999) found a lower rate of farm exit among large land owners in the United states and Canada.[10]

ii))Education: People lacking qualifications or with limited schooling are poverty-prone. They are more frequently unemployed and are more likely to be unemployed long-term. They are also more likely to belong to the "working poor" and are generally less able to cope with life crises.

Additional courses and training sessions, learning on the job and recognition of migrants' qualifications can be helpful.

iii) Agriculture: Agriculture remains the livelihood of most of the poorest people in India. In most of the villages of India agricultural economy characterized by dependence on nature, low investment ,low productivity, 
mono-cropping with paddy as the dominant crop, in inadequate irrigation facilities and small and marginal holdings. The dependence of agriculture on the Vagaries of the rain-god can be gauged from the fact that the large area of the total cultivated area is un-irrigated. Adverse climatic condition, like draught and floods, plays a role in decreasing products. Agriculture continues to be an important source of income for rural households across all income levels. In fact a substantial body of evidence supports the relationship between agricultural productivity growth and poverty reduction, demonstrating generally high poverty reduction elasticity for agricultural productivity growth (Hazell 2010 ; Pingali 2010 ). Worldwide agricultural growth has been consistently shown to be more effective in reducing poverty than comparable growth in other economic sectors; for instance, on average a $1 \%$ increase in the agricultural growth rate has been estimated to reduce poverty by $1.6 \%$ more than equal growth in industrial sectors and by three times more than in service sectors (Christiaensen and Demery 2007 ).[11]

iv) Living conditions with ICT:Here we mean living in safety, peace and dignity. This includes having privacy, space, security, light, and electricity and gas within your own four walls, as well as affordable means of transportation and most important is ICT(information communication and technology) in the vicinity. Families with low incomes often live in run-down, cramped and poorly-equipped housing in a congested and noisy environment exposed to exhaust, lacking parks and difficult to access by public transport and ICT. In rural India, as in much of the developing world, direct ownership and use of ICT -for instance through a PC with Internet access- applies only to a very small fraction of the population. Although the availability of content in local languages and the use of graphic and voice interfaces can make ICT applications more accessible to poor people, illiteracy, low levels of education are all powerful obstacles

to the use of computers and other ICT tools. It follows that, in most cases, poor people have to rely on a human intermediary between them and ICT, in what is termed a "reintermediation model" [12] The profile of the intermediaries who add human skills and knowledge to the presence of ICT is thus critical for projects that want to reach the poor.[13]

v) Housing:_Housing for a homeless person or moving to a larger, better-equipped and more accessible home usually improves living conditions and can achieve sustainable livelihood immediately. Better house or pucca house give better livelihood and is more hygienic than kuchha house.

vi) Drinking water(Health): Water is a vital part of the socio-ecological system, providing life support for humans, animals, and the environment. Integrated management of water resources should be based on water as an integral part of the ecosystem involving both biophysical and social characteristics. Declining per capita land and fresh water availability, coupled with degrading land and water resources, pose serious threats to food, environmental, social, and economic security, especially in developing countries like India.[14]

Increased education and water quality, measured by the proportion of people drinking from unprotected water sources, were most clearly associated with decreases in poverty. These variables are significant and relatively stationary across the study area, and can therefore be addressed with whole-of-catchment-scale policies with less attention to regional differences. A statistical relationship between water quality and child health poverty measures seems consistent with the vital role given to water and sanitation in alleviating poverty (UNDP/SEI 2006). Insufficient access to clean water is known to impact on human health, through the development of water-borne diseases (e.g. diarrhoea, cholera) and water-washed diseases (e.g. scabies, trachoma) (Bradley 1974). Diarrhoea is the cause of child mortality in many places.[15]

vii)Sanitation: The Total Sanitation Campaign (TSC) launched in 1999, has been now renamed as Nirmal Bharat Abhiyan (NBA) with the objective "to accelerate the sanitation coverage in the rural areas so as to comprehensively cover the rural community through renewed strategies and saturation approach". The NBA aims to promote rural well-being through environmentally safe disposal and utilization of rural household wastes, and therefore, is inherently a green programme. The NBA can improve the rural environment by converting rural household wastes to organic fertilizer, fuel and water for irrigation and groundwater recharge.

Cover story in "Outlook oct 21, 2013" Magazine by Uttam Sengupta: 34-38 pages. India's second largest problem is sanitation. Open defecation releases methane into air, a gas that is 21 times more harmful than $\mathrm{CO}_{2}$.

Toilet Status:

$64 \%$ of Indians defecate in the open.

$60 \%$ of all open defecations in the world are in India

45,000 crore rupees spent on rural sanitation during the last five years.

(Source: Census of India's Housing Census Data, 2011) 
Kerala, Himachal Pradesh and Sikkim are the first 'Nirmal Rajya' states 100\% open defecation-free.[16]

viii) Cooking Fuel: Energy using appliances often require significant capital outlay relative to the household income. Thus, even if electricity were to become available, most households may not be able to use their electricity because of a lack of electrical appliances. Compared to wealthier, electrified households, low income mainly rural households suffer high levels of harmful emissions from local fuel use. Although emissions are released when coal is burnt in power stations, these are dispersed into the atmosphere through very tall stacks so that their concentration drops to low levels before it reaches people. By contrast the emissions from burning wood and coal in households are highly concentrated and slow moving. Electricity and LPG is therefore considered a clean fuel for households.[17]

ix) Income: A relatively fast pace of growth during the decade 1995-2005 and beyond

has shifted India to a higher economic spiral which was never observed in its recorded history. Notwithstanding most recent slowdown and recession like situation, Indian growth story is still relevant and one expects that the fruit of progress will also be available to lower sections of the society. A dominant way macro growth percolates down is through opportunities to work and improve labour productivity which is reflected in higher wages and household income. Growth in rural non-farm employment and associated income is considered one of the dominant responses of a pro-poor growing economy which not only enhances incomes but also sustains them. For example, sectoral transformation that has characterized Southeast Asia during last three to four decades viz., large and rapid shift of labour from agriculture to industry and movement of people from villages to cities are by now well documented (Chong-Yah Lim, 2001: 14). In India, the decline was broadly similar, albeit a bit slower -from 49 per cent in the early 1950s to 18 per cent in recent years. But, the share of labour force in agriculture declined precipitously in Thailand - from 83 per cent in the early 1960s to about 50 per cent in recent years.

In contrast, the decline in Indian agriculture's share of labour force was only marginal; it fell from 75 per cent in early 1950s to merely about two thirds in recent years (Economic Survey, 2008), reflecting relatively slow movement of agricultural workers to non-agricultural employment, which in turn is a manifestation of poor growth of labour-intensive industries in the country. Given still higher rate of growth of labour force which is about 1.8 to 2 per cent in India, it is absolutely essential that new work opportunities outside agriculture, especially in non-farm entrepreneurship and business sectors, emerge in large scale. Surprisingly, there is little systematic research, and even less policy discussion, about the sect oral patterns of employment growth and shifts in employment from rural, traditional and low-productivity occupations to non-farm, modern and higherproductivity occupations across different countries of South Asia, especially India.[18]

When you lack the money to buy what you need and to help your family, then you are very poor. In our society, money is everything. If you do not have money, then no one respects you. In fact people will spit on you in the street. [19]

x) Expenditure: Poverty manifests itself in many ways. Basic needs are often unfilled; food consumption may be below minimum caloric requirement for at least part of the year; incomes are often too low to satisfy basic food and non-food needs; access to health facilities, schooling, minimum housing and clothing, safe drinking water and sanitation is often lacking. At times of crises such as illness, accidents, natural or man-made disasters, or events requiring lump-sum expenditure, the poor lack the assets or social security nets to master these contingencies. They risk getting trapped in a downward spiral. Material deprivation is compounded by physical and by psychological harassment, stereotypes and prejudices. These different physical, economic, social, cultural and socio-psychological dimensions are distinct but related, and illustrate the multifaceted nature of poverty.

Change in one dimension of poverty can lead to changes in other dimensions, illustrating the interlocking and mutually reinforcing nature of poverty. Better health improves one's working capacity. On the other hand, change in one sphere may not last, if other dimensions do not also change. Only multifaceted positive change can break the vicious cycle of poverty. For the purpose of monitoring and intervention by external agencies, poverty is usually defined in terms of only one or relatively few dimensions. Measurement based on basic needs, such as the incidence and severity of nutritional deficiency, morbidity and mortality rates, water supply and sanitation facilities, housing conditions, education and health facilities, are most useful in designing programmes or policies specifically geared to those problems. On the other hand, the minimum income (poverty line) approach makes it possible to formulate policies and programs that influence employment generation, agricultural production, income and prices. However, problems are likely to arise when a priority conclusion about one dimension of poverty is drawn from measurements based on another (Kumar, 1985). Standards and cut-off points are widely used to define the levels that are considered to be insufficient for minimal well-being. By defining these standards, a population can be divided in the nonpoor, poor and ultrapoor. Different definitions of poverty define different people as poor. Correlations among different definitions of poverty identifying "the poor" in a certain population may be weak (Glewwe and Van der Gaag, 1990). For 
example, even the normal ranking of different regions varies according to the definition of poverty used (Mellor and Desai, 1985). Designing meaningful poverty measures is therefore a matter of recognising poverty as a human predicament experienced by millions of people throughout the world.

Its definition provides a precursor to the design of means to improve interventions to reduce poverty, rather than just a "technical" matter of "getting the poverty line right" (Ravnborg, 1998). Partial measures that only reflect a single aspect of poverty such as income or expenditure have therefore come to be seen as inadequate measures of poverty. In addition, there is an emerging recognition that poverty should not be perceived only as a state of deprivation but also as a set of processes that lead to and identify a state of deprivation. Analysis of poverty perceptions has also indicated that a wide range of socio-economic variables must be considered to fully encompass the nature of poverty. Clearly, any analysis that focuses only on an income-based threshold and ignores other factors will provide only a limited understanding of the nature of the poverty (Watson, 2000). [20]

\section{B). Weight assignment for SLD}

\begin{tabular}{|cll|}
\hline SLD no. & \multicolumn{1}{c|}{ SLD } & *Weight factor $\left(\mathrm{W}_{\mathrm{f}}\right)$ \\
\hline 1. & Land & 06 \\
2. & Professional Education & 10 \\
3. & Agriculture & 09 \\
4. & Living condition with ICT & 08 \\
5. & Housing & 06 \\
6. & Drinking Water(Health) & 06 \\
7. & Sanitation(Health) & 07 \\
8. & Cooking fuel & 05 \\
9. & Income & 07 \\
10. & Expenditure & 07 \\
\hline
\end{tabular}

*Assigning a weight factor to each sustainable livelihood dimension based on the dimension's effect for sustainability in rural livelihood.

\section{C). Scheme of awarding Points to each dimension}

Table 12: Scheme of awarding Points to each dimension

\begin{tabular}{|c|c|c|c|c|c|c|}
\hline $\begin{array}{l}\text { SLD } \\
\text { No.Pt. }\end{array}$ & 0 & 1 & 2 & 3 & 4 & 5 \\
\hline $\mathrm{SLD}_{1}$ & Nil & $<=2$ acre & $2-5$ acre & 5-10acre & $10-20$ acre & $>20$ acre \\
\hline $\mathrm{SLD}_{2}$ & Upte High school & Inter & Graduate & - & - & PG \& Professional courses \\
\hline $\mathrm{SLD}_{3}$ & $\begin{array}{l}\text { Old \& manual faming } \\
\text { methods }\end{array}$ & $\begin{array}{l}\text { Old faming \& manual } \\
\text { farming methods with } \\
\text { fertilizers }\end{array}$ & $\begin{array}{l}\text { Old faming \& manual } \\
\text { farming methods with } \\
\text { fertilizers, treated seeds }\end{array}$ & $\begin{array}{l}\text { treated seeds with green } \\
\text { manures and vemi- } \\
\text { compost, Inter cropping } \\
\text { methods }\end{array}$ & $\begin{array}{l}\text { Fertilizers, treated seeds, } \\
\text { new ingation methods }\end{array}$ & $\begin{array}{l}\text { Fertilizers, imported seeds, } \\
\text { New imigations methods, new } \\
\text { equipments and training. }\end{array}$ \\
\hline $\mathrm{SLD}_{4}$ & $\begin{array}{c}\mathrm{Nil} \text {, old } \\
\text { communicatio } \\
\mathrm{n} \text { sytems }\end{array}$ & Mobile & Radio, Mobile, TV, & Radio, Mobile, TV, LL & $\begin{array}{c}\text { Radio, Mobile, T V, LL, } \\
\text { Computers }\end{array}$ & $\begin{array}{l}\text { Computers, Laptop, ATM, } \\
\text { Software, e-leaming }\end{array}$ \\
\hline $\mathrm{SLD}_{5}$ & Kutcha House & - & - & - & - & Pucca House \\
\hline SLD $_{6}$ & $\begin{array}{l}\text { Lake, River, canal, } \\
\text { Ponds }\end{array}$ & Well water(unprotected) & Tap water & Mobile tanks, Tube wells & Well water protected & Hand Pump, Boring water \\
\hline $\mathrm{SLD}_{7}$ & Open space & - & - & - & - & Toilets \\
\hline $\mathrm{SLD}_{8}$ & $\begin{array}{l}\text { Wood, Leaf, cow dung, } \\
\text { coal, Kerosene }\end{array}$ & Stove, electric heater & & - & Solar heater & LPG, Bio- Gas \\
\hline $\mathrm{SLD}_{9}$ & Nil & $0-5000$ & $5000-10000$ & $10,000-15,000$ & $15,000-20,000$ & $>=20,000$ \\
\hline $\mathrm{SLD}_{10}$ & Nil & $0-1000$ & $1000-2000$ & $2000-5000$ & $5000-10,000$ & $y=10,000$ \\
\hline
\end{tabular}

LL-Land Line phones, T V-Television 


\section{D). Evaluation Matrix}

Table13: Weighted SLD Evaluation Matrix for Nayatoli.

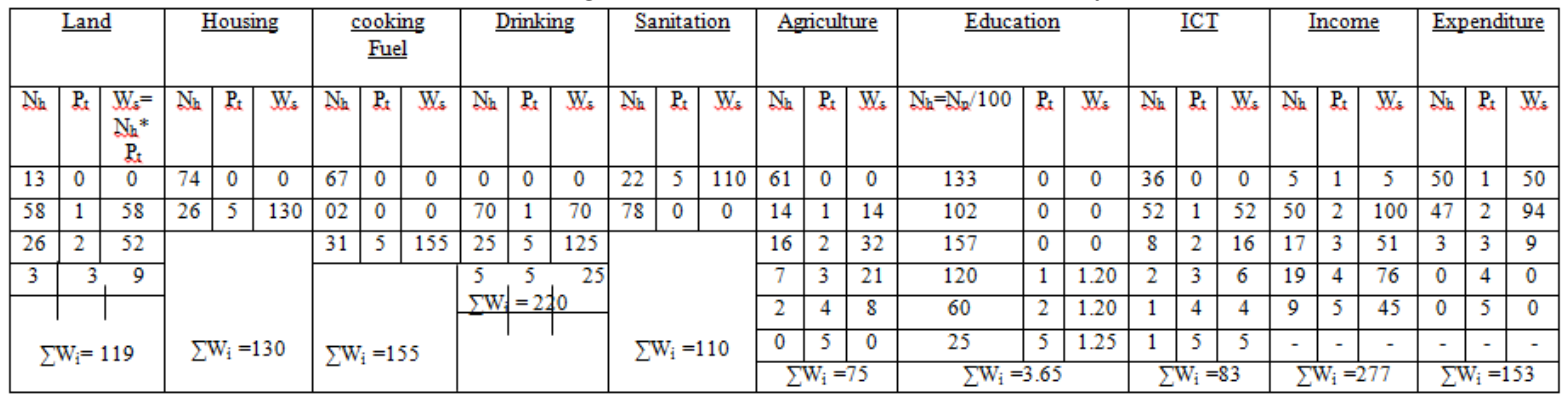

$\mathrm{SLD}_{\mathrm{v}}=\sum \mathrm{W}_{\mathrm{i}} * \mathrm{~W}_{\mathrm{f}} \mathrm{N}_{\mathrm{h}=}$ No. of house, $\mathrm{P}_{\mathrm{t}}=$ point assign to the particular dimension, $\mathrm{Ws}=\mathrm{Wight}$ factor $\left(\mathrm{N}_{\mathrm{h}} * \mathrm{P}_{\mathrm{t}}\right)$

Table14: Weighted SLD Evaluation Matrix for Jhabar

\begin{tabular}{|c|c|c|c|c|c|c|c|c|c|c|c|c|c|c|c|c|c|c|c|c|c|c|c|c|c|c|c|c|c|}
\hline \multicolumn{3}{|c|}{ Land } & \multicolumn{3}{|c|}{ Housing } & \multicolumn{3}{|c|}{$\frac{\text { cooking }}{\text { Fuel }}$} & \multicolumn{3}{|c|}{ Drinking } & \multicolumn{3}{|c|}{$\underline{\text { Sanitation }}$} & \multicolumn{3}{|c|}{ Agriculture } & \multicolumn{3}{|c|}{ Education } & \multicolumn{3}{|c|}{$\underline{\mathrm{ICT}}$} & \multicolumn{3}{|c|}{ Income } & \multicolumn{3}{|c|}{ Expenditure } \\
\hline $\mathrm{Nh}_{\mathrm{h}}$ & $P_{t}$ & $\begin{array}{c}\mathrm{W}_{\mathrm{s}}= \\
\mathrm{N}_{\mathrm{k}}{ }^{*} \\
\mathrm{P}_{\mathrm{t}}\end{array}$ & $\mathrm{N}_{\mathrm{h}}$ & $\mathrm{Pt}$ & $\mathrm{W}_{5}$ & $\mathrm{~N}_{h}$ & Ptt & $\mathrm{W}_{\mathrm{s}}$ & $\mathrm{N}_{\mathrm{h}}$ & $P_{t}$ & $\mathrm{~W}_{s}$ & $\mathrm{~N}_{\mathrm{h}}$ & $P_{t}$ & $\mathrm{~W}_{5}$ & $\mathrm{~N}_{\mathrm{b}}$ & $P_{t}$ & $\mathrm{~W}_{\mathrm{s}}$ & $\mathrm{N}_{\mathrm{h}}$ & $P_{t}$ & $\mathrm{~W}_{\mathrm{s}}$ & $\mathrm{N}_{\mathrm{k}}$ & $P_{t}$ & $\mathrm{~W}_{s}$ & $\mathrm{~N}_{\mathrm{k}}$ & $\mathrm{P}_{t}$ & $\mathrm{~W}_{\mathrm{s}}$ & $\mathrm{N}_{h}$ & $\mathrm{P}_{\mathrm{t}}$ & $\mathrm{W}_{s}$ \\
\hline 31 & 0 & 0 & 16 & 0 & 0 & 55 & 0 & 0 & 26 & 2 & 52 & 44 & 5 & 220 & 59 & 0 & 0 & 112 & 0 & 0 & 44 & 0 & 0 & 44 & 1 & 44 & 53 & 1 & 53 \\
\hline 11 & 1 & 11 & 84 & 5 & 420 & 01 & 0 & 0 & 66 & 1 & 66 & 56 & 0 & 0 & 11 & 1 & 11 & 52 & 1 & .52 & 51 & 1 & 51 & 28 & 2 & 56 & 44 & 2 & 88 \\
\hline 57 & 2 & 114 & \multirow{3}{*}{\multicolumn{3}{|c|}{$\sum \mathrm{W}_{\mathrm{i}}=420$}} & 44 & 5 & 220 & 06 & 5 & 30 & \multirow{3}{*}{\multicolumn{3}{|c|}{$\sum \mathrm{W}_{\mathrm{i}}=220$}} & 23 & 2 & 46 & 164 & 2 & 3.28 & 4 & 2 & 8 & 0 & 3 & 0 & 3 & 3 & 9 \\
\hline \multirow{2}{*}{\multicolumn{3}{|c|}{$\sum W_{i}=128$}} & & & & \multirow{2}{*}{\multicolumn{3}{|c|}{$\Sigma W_{i}=220$}} & \multirow{2}{*}{\multicolumn{3}{|c|}{58}} & & & & 0 & 5 & 0 & 20 & 5 & 1.00 & 0 & 5 & 0 & - & - & - & - & - & - \\
\hline & & & & & & & & & & & & & & & \multicolumn{3}{|c|}{$\frac{1}{\sum W_{i}}=8$} & \multicolumn{3}{|c|}{$\sum W_{i}=8.32$} & \multicolumn{3}{|c|}{$\sum \mathrm{W}_{\mathrm{i}}=63$} & \multicolumn{3}{|c|}{$\sum W_{i}=228$} & \multicolumn{3}{|c|}{$\frac{1}{\Sigma W_{i}}=150$} \\
\hline
\end{tabular}

$\mathrm{N}_{\mathrm{h}}$ No. of house, $\mathrm{P}_{\mathrm{t}}=$ point assign to the particular dimension, Ws=Wight factor $\left(\mathrm{N}_{\mathrm{h}} * \mathrm{P}_{\mathrm{t}}\right)$

Table15: Weighted SLD Evaluation Matrix for Gopalpur.

\begin{tabular}{|c|c|c|c|c|c|c|c|c|c|c|c|c|c|c|c|c|c|c|c|c|c|c|c|c|c|c|c|c|c|}
\hline \multicolumn{3}{|c|}{$\underline{\text { Land }}$} & \multicolumn{3}{|c|}{ Housing } & \multicolumn{3}{|c|}{$\begin{array}{l}\text { cooking } \\
\text { Fuel }\end{array}$} & \multicolumn{3}{|c|}{ Drinking } & \multicolumn{3}{|c|}{ Sanitation } & \multicolumn{3}{|c|}{ Agriculture } & \multicolumn{3}{|c|}{ Education } & \multicolumn{3}{|c|}{$\underline{\mathrm{ICT}}$} & \multicolumn{3}{|c|}{ Income } & \multicolumn{3}{|c|}{ Expenditure } \\
\hline $\mathrm{Nh}_{\mathrm{h}}$ & $\mathrm{P}_{\mathrm{t}}$ & $\begin{array}{l}\mathrm{W}_{\mathrm{s}}= \\
\mathrm{N}_{\mathrm{h}}{ }^{*} \\
\mathrm{P}_{\mathrm{t}}\end{array}$ & $\mathrm{N}_{\mathrm{h}}$ & $\mathrm{P}_{t}$ & $\mathrm{~W}_{\text {s }}$ & $\mathrm{N}_{\mathrm{h}}$ & $\mathrm{P}_{\mathrm{t}}$ & $\mathrm{W}_{3}$ & $\mathrm{~N}_{h}$ & $\mathrm{P}_{t}$ & $\mathrm{~W}_{s}$ & $\mathrm{~N}_{h}$ & $P_{t}$ & $\mathrm{~W}_{\mathrm{s}}$ & $\mathrm{N}_{h}$ & $\mathrm{P}_{\mathrm{t}}$ & $\mathrm{W}_{\mathrm{s}}$ & $\mathrm{N}_{\mathrm{h}}$ & $\mathrm{P}_{\mathrm{t}}$ & $\mathrm{W}_{\mathrm{s}}$ & $\mathrm{Nh}_{\mathrm{h}}$ & $\mathrm{P}_{t}$ & $\mathrm{~W}_{\mathrm{s}}$ & $\mathrm{N}_{\mathrm{h}}$ & $\mathrm{P}_{t}$ & $\mathrm{~W}_{\mathrm{s}}$ & $\mathrm{N}_{\mathrm{h}}$ & $\mathrm{P}_{\mathrm{t}}$ & $\mathrm{W}_{s}$ \\
\hline 10 & 0 & 00 & 11 & 0 & 0 & 74 & 0 & 0 & 91 & 2 & 182 & 17 & 5 & 85 & 69 & 0 & 0 & 392 & 0 & 0 & 47 & 0 & 0 & 0 & 0 & 0 & 0 & 0 & 0 \\
\hline 87 & 1 & 87 & 89 & 5 & 445 & 3 & 0 & 0 & 0 & 1 & 0 & 83 & 0 & 0 & 21 & 1 & 21 & 77 & 1 & .77 & 46 & 1 & 46 & 27 & 1 & 27 & 94 & 1 & 94 \\
\hline 3 & 2 & 06 & \multirow{5}{*}{\multicolumn{3}{|c|}{$\sum W_{i}=445$}} & 23 & 5 & 115 & 2 & 5 & 10 & \multirow{5}{*}{\multicolumn{3}{|c|}{$\sum W_{i}=85$}} & 4 & 2 & 8 & 46 & 2 & .92 & 5 & 2 & 10 & 55 & 2 & 110 & 6 & 2 & 12 \\
\hline \multirow{4}{*}{\multicolumn{3}{|c|}{$\sum \mathrm{W}_{\mathrm{i}}=93$}} & & & & \multirow{4}{*}{\multicolumn{3}{|c|}{$\sum W_{i}=115$}} & 7 & 5 & 35 & & & & 5 & 3 & 15 & 18 & 4 & .72 & 1 & 3 & 3 & 4 & 3 & 12 & 0 & 3 & 0 \\
\hline & & & & & & & & & & & & & 3 & 4 & 12 & 4 & 4 & .16 & 1 & 4 & 4 & 7 & 4 & 28 & 0 & 4 & 0 \\
\hline & & & & & & & & & & & & & & & 0 & 5 & 0 & 2 & 5 & .10 & 0 & 5 & 0 & 7 & 5 & 35 & 0 & 5 & 0 \\
\hline & & & & & & & & & & & & & & & & $\bar{N}_{\mathrm{i}}=$ & & & $i=2$ & & & $\mathrm{~N}_{\mathrm{i}}=$ & & & $\mathrm{N}_{\mathrm{i}}=2$ & & & $\bar{\gamma}_{\mathrm{i}}=$ & \\
\hline
\end{tabular}

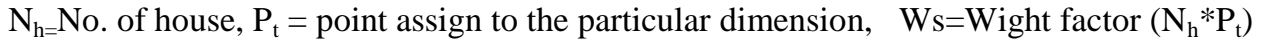

Table 16: Indicators value obtained for three villages.

\begin{tabular}{ccccc}
\hline SLD & *Weight factor $\left(\mathbf{W}_{\mathbf{f}}\right)$ & Nayatoli & Jhabar & Gopalpur \\
\hline $\mathbf{1}$ & 06 & 714 & 768 & 558 \\
$\mathbf{2}$ & 10 & 36.5 & 83.2 & 26.7 \\
$\mathbf{3}$ & 09 & 675 & 720 & 504 \\
$\mathbf{4}$ & 08 & 664 & 504 & 504 \\
$\mathbf{5}$ & 06 & 780 & 1680 & 2670 \\
$\mathbf{6}$ & 06 & 1320 & 948 & 1362 \\
$\mathbf{7}$ & 07 & 770 & 1540 & 595 \\
$\mathbf{8}$ & 05 & 775 & 880 & 575 \\
$\mathbf{9}$ & 07 & 1939 & 1596 & 1484 \\
$\mathbf{1 0}$ & 07 & 1071 & 1050 & 742 \\
\hline
\end{tabular}

\section{E).Survey Process}

A survey of households was conducted in three states of India-Jharkhand, Chattisgarh, and Utter Pradesh.Considering above mention dimensions we have made a questionnaire (Annexure) consisting of forty two queries. The questionnaire consisted of many questions with sub sections. It focused on various important 
determinants of measuring sustainable livelihood such as education, health, landholdings, assets, employment, income, consumption expenditure, savings, indebtedness, migration etc. Survey and interviewed people in different villages by the help of government officials, people of village, panchayat, and blocks.

We selected 100 households in each village. Structured questionnaires were administered to generate information related to the sustainable livelihood dimensions among the rural people. Through our questionnaires, we have constructed the profile of livelihood and try to identify the optimal indicators of sustainable livelihood of different villages. The survey was conducted during the period of October 2013 and May 2013 to June 2013.

In Ranchi district surveyed village is Nayatoli which comes in Kanke block under Mesra East Panchayat. In this Panchayat total no. of household is 1879 and population is 9396.

In Ghazipur district surveyed village is Gopalpur which comes in Saidpur block under Gopalpur panchayat.Total no. of households are 668 in this panchayat and population is 4013.

In Korba district surveyed village is Jhabar which comes in Korba block under Jhabar panchayat. Total no. of households 611 and population is 2828 respectively. [21]

Despite these limitations the comparative findings have been extremely valuable, especially when sustainable livelihood discourse faces new questions in the face of globalization.

\section{Conclusion}

By observation we found that education including professional education, ICT and agriculture is very less in all the villages surveyed. This indicates that these three are major factors for unsustainable livelihood for rural people. These indicators are optimal to find the sustainable livelihood to any district. Therefore we have selected these three indicators to achieve sustainable livelihood which is one of the part to achieve sustainability livelihood for poor in India.

\section{Result}

We found that following three major indicators may be considered to achieve the sustainable livelihood for poor in India.

1) Education.(Technical and Professional Education after counseling)

2) Agriculture.

3) Information Communication Technology.

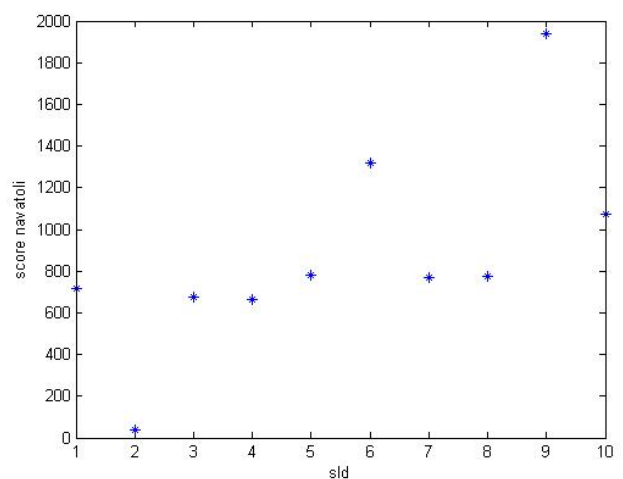

Fig: 5(A)SLDs score for Nayatoli

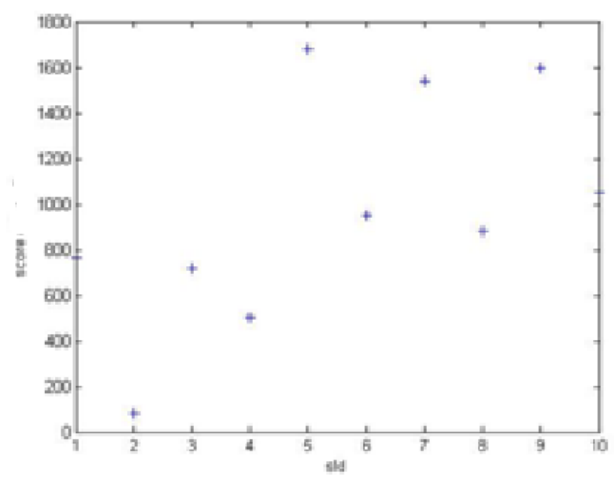

Fig:5(C) SLDs score for Jhabar

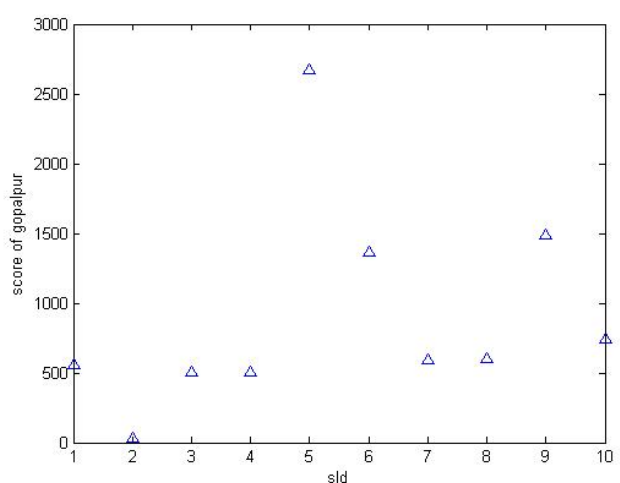

Fig:5(B) SLDs score for Gopalpur

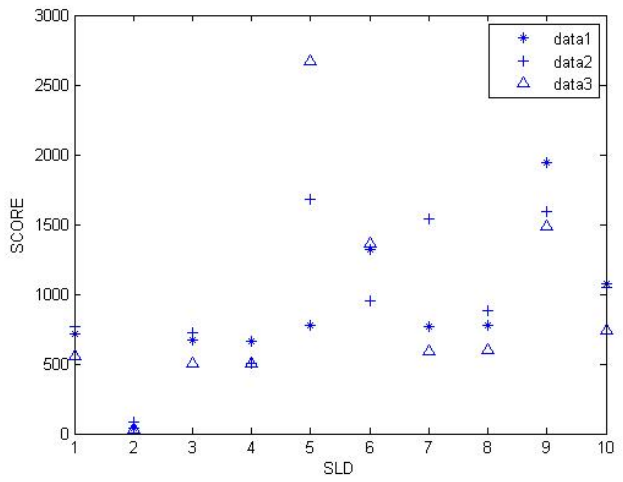

Fig:5(D)Comparative result 


\section{Future Scope:}

The sample size can be increased by increasing the no. of states, districts, and villages. This work is intended for rural area which can be implemented for urban area and dimensions can be increased or decreased according to the selection of area.

\section{Annexure}

The following questionnaire were used to collect the primary data for table 2 to table 11

गाँव :

ब्लाक :

स्थान :

PART - A

1. घर के मुखिया का नाम ?

2. घर में कितने सदस्य हैं ? महिलाएँ, पुरुष, और बच्चे कितने हैं ?

3. पिछले दो साल में किसी की मृत्यु हुई है ? संख्या कितनी है ?

4. घर से बाहर कितने लोग गये हैं, काम करने के लिए ?

5. घर में 15 से नीचे के कितने सदस्य हैं ?

6. घर में 55 साल से उपर के कितने सदस्य हैं ?

7. Total Income हर महीने कितनी है ?

8. धन अर्जित करने का साधन क्या है ?

9. घर के कितने लोग Service कर रहें हैं या Business कर रहे हैं ?

10. घर की कितनी महिला सर्विस कर रही हैं या अपना धन अर्जन करती हैं ?

\section{$\underline{\text { PART - B }}$}

11. हर सप्ताह करबी कितना खर्च होता है ? (जैसे खाने-पीने में ) या कुछ अलग खर्च है तो क्या है ?

12. उधार कितना लेते हैं, दूसरों से हर महीने ?

13. अगर जमीन है तो कितनी है ?
अ. नहीं है।
ब. 2 एकड ( 2 एकड के कम)
स. 2-5 एकड
द. 5-10 एकड

14. बी.पी.एल. काई है या नहीं है ?

15. पेंशन काई है या नहीं ?

16. पक्का घर है या कच्चा घर ?

17. बैंक में सेविंग एकांउट है या नही ?

of 


\section{PART - C}

18. परिवार संयुक्त है या एकल है ?

19. परिवार किस Category में आता है ?
अ. $\mathrm{SC}$
ब. ST
स. $\mathrm{OBC}$
द. GENERAL

20. पाँच साल से बीचिे कोई अनपढ है ? कितने हैं ?

21. Primary Education घर के कितने सदस्यों के किया है ?

22. Middle School पास कितने सदस्य हैं ?

23. 10 वी पास कितने सदस्य हैं ?

24. Inter Pass कितने सदस्य हैं ?

25. Graduate या स्नातक कितने लोग हैं ?

26. Professionals (किसी कार्य में निपुर्ण जिससे धन अर्जित किया जाऐ)

कितने हैं ?

27. कोई साधारण बिमारी है जिससे घर के सदस्य बार-बार बीमार

हो रहें हैं ?

28. जन्म लिया हुआ बच्चा, जन्म के दौरान कम वजन का था या कि

ठीक था ?

29. Normal (बिना बिमारी) बच्चे घर में कितने बच्चे पैदा लिये हैं ?

3०. समय से पहले ( 9 महीने से) कोई बच्चा पैदा हुआ है ? संख्या ?

31. घर में कितने बच्चों को $\mathrm{BCG}$ का टीका लगा है ?

32. घर में कितने बच्च्चों को DPT का टीका लगा है ?

33. घर में कितने बच्चों को Polio का टीका लगा है ?

34. पीने का पानी कहाँ से लेते हैं ?

35. घर में Toilet है या नहीं ?

36. खाना बनाने के लिए ईंधन क्या इस्तेमाल करते हैं ?

37. घर मे वाहन है या नहीं ? है तो कौन सा है ? 
38.निम्नलिखित में खेती से संबंधित क्या-क्या इस्तेमाल करते हैं? a)बिल्कुल पुरानी विधि

b) उर्वरक का इस्तेमाल

c)उर्वरक और उपचारित बीज

d)वेर्मि कोम्पोस्त , ग्रीन manure, इंतेरक्रोप्पिंग method

e) नए सिंचाई के साधन, उपचारित बीज, उर्वरक

f)उपरोक्त सभी और ट्रेनिंग प्रोग्राम

39. घर में निम्नलिखित में से क्या उपलब्ध है?

a)मोबाइल

b) टेलीविजन

c)रेडियो

d)कंप्यूटर

e)टेलीफोन

40. इंटरनेट है या नहीं?

41. कोई सॉफ्टवेयर है या नहीं?

42. एटीएम इस्तेमाल करतें हैं या नहीं? 


\section{References}

[1]. Roger A. Petry, Educating for sustainable production and consumption and sustainable livelihoods: learning from multistakeholder networks, Sustainability Science, Springer, (6) 2011,83-96.

[2]. Stephen Morse and Nora McNamara and Moses Acholo, Sustainable Livelihood Approach: A critical analysis of theory and practice. 2009, Geographical Paper No. 189

[3]. http://jharkhandindustry.gov.in/Concept\%20note\%20on\%20JEXCOM.pdf

[4]. http://Uttar Pradesh Natural Resources Forests Rivers Minerals.mht

[5]. Planning Commission of India 2004-05.

[6]. Census 2001 data on the population of three socially excluded groups - scheduled castes, scheduled tribes and Muslims - as a percentage of the total population.

[7]. http://chhattisgarh.nic.in/vision/new/chp\%205\%20-20unlocking\%20natural\%20wealth.pdf

[8]. http://www.consumerschoice.kbo.co.ke/products

[9]. $\quad$ P.B. Bhandari , Journal of Rural Studies, Elsevier, (32 ),2013, 126- 36.

[10]. Kate Schneider and Monika Zurek, Poverty, Agriculture and the Environment:The Case of Sub-Saharan Africa Prabhu Pingali , Pg 151-168

[11]. R. Heeks, Understanding e-Governance for Development. i-Government working Paper Series, Paper No. 11, 2001.http://www.idpm.man.ac.uk/idpm/igov11abs.htm.

[12]. Can information and communications technology applications contribute to poverty reduction? Lessons from rural India; Simone Cecchini and Christopher Scott, Information Technology for Development, (10)2003, 73-84.

[13]. Exploring options of participatory water management for livelihood improvements in the Indo-Gangetic Basin, Intl. J. River Basin Management ( 7), 2, 2009, 147-155 .

[14]. Water, agriculture and poverty in the Niger River basin, Andrew Ogilvie, Gil Mahe, et al. Water International; ( 35 ), 5, September 2010, 594-622.

[15]. Outlook Oct 21, 2013" Magazine by Uttam Sengupta: 34-38 pages

[16]. M.I. Howells, T. Alfstad, N. Cross and L.C. Jeftha, Rural Energy Modeling, 2002.

[17]. Abusaleh Shariff, Rural Income and Employment Diversity in India During 1994 and 2005, Journal of Developing Societies; SAGE, (25) 2: 2009, 65-208.

[18]. Rufus B. Akindola, Towards a Definition of Poverty Poor People's Perspectives and Implications for Poverty Reduction, sage (25) 2, 2009, 121-150.

[19]. Dariush Hayati, Ezatollah Karami And Bill Slee, Combining Qualitative And Quantitative Methods In The Measurement Of Rural Poverty: The Case Of Iran; Social Indicators Research,Springer (75), 2006, 361-394

[20]. http://indiawater.gov.in/imisreports 